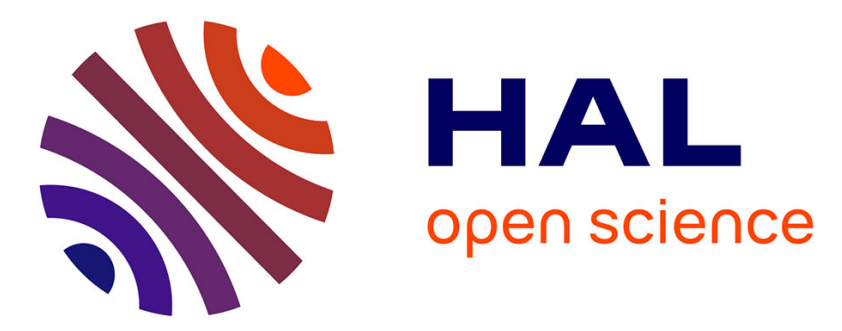

\title{
A retreat in a South Korean Buddhist monastery: Becoming a lay devotee through monastic life
}

Florence Galmiche

\section{To cite this version:}

Florence Galmiche. A retreat in a South Korean Buddhist monastery: Becoming a lay devotee through monastic life. European Journal of East Asian Studies, 2010, 9 (1), pp.47-66. 10.1163/156805810X517661 . hal-02310460

HAL Id: hal-02310460

https: / hal-univ-paris.archives-ouvertes.fr/hal-02310460

Submitted on 10 Oct 2019

HAL is a multi-disciplinary open access archive for the deposit and dissemination of scientific research documents, whether they are published or not. The documents may come from teaching and research institutions in France or abroad, or from public or private research centers.
L'archive ouverte pluridisciplinaire HAL, est destinée au dépôt et à la diffusion de documents scientifiques de niveau recherche, publiés ou non, émanant des établissements d'enseignement et de recherche français ou étrangers, des laboratoires publics ou privés. 


\title{
A retreat in a South Korean Buddhist monastery:
}

\section{Becoming a lay devotee through monastic life}

Florence GALMICHE

\section{Preprint version.}

Paper published in : European Journal of East Asian Studies, 9, no. 1 (2010): 47-66.

\begin{abstract}
:
In South Korea, the distance between Buddhist monastics and lay devotees tends to reduce as monasteries and temples multiply in urban areas. Even the remote mountain monasteries have, for a large number, broadened their access to the lay visitors. Nowadays monastic and lay Buddhists have more occasions to meet than before and the current intensification of their relationships brings important redefinitions of their respective identities. The purpose of this paper is to explore to what extent and limits this new spatial proximity does signify a rapprochement between the monastic and the lay Buddhists. Through an ethnographic approach and a participant observation methodology I focus on the case of a one-week retreat for laity in a Buddhist monastery dedicated to meditation. This case study examines the ambiguous goal of this retreat program that combined two aims: initiating the lay practitioners to the monastic lifestyle and to the practice of kanhwa sŏn meditation, and also establishing a group of lay supporters affiliated to the temple. This temporary monastic experience was directed toward an intense socialisation of the participants to the norms and values of an ascetic lifestyle and, for a while, blurred some aspects of the border between lay and monastic practices of Buddhism. However, this paper presents the idea that this transitory rapprochement contributed to both challenge and strengthen the distinction between renouncers (ch'ulga) and householders (chaega).
\end{abstract}

Keywords: Buddhism, Korea, monastery, laity, legitimacy, meditation, asceticism

Studies on Korean Buddhism generally emphasise its monastic and intellectual side, focusing especially on texts, outstanding monks, and theoretical debates. Also, research conducted on the social and practical aspects of Korean Buddhism mainly highlights the monastic community as its very core. ${ }^{1}$ This focus on the monastic part of the samgha ${ }^{2}$ underlines its driving role in the vitality of the Buddhist tradition, as

\footnotetext{
${ }^{1}$ Robert E. Buswell, The Zen Monastic Experience: Buddhist Practice in Contemporary Korea (Princeton: Princeton University Press, 1992). This book is a major reference concerning the practical and everyday dimensions of Korean Buddhism. It provides detailed descriptions of the monastic practices, organisation and lifestyle.

${ }^{2}$ Sanskrit expression samgha (Korean sŭn'ga 僧伽) refers to the community of Buddhist practitioners. It has several definitions but the four-fold samgha (in Korean sabudaejung 四 部大衆) is composed of monks, nuns, laymen and laywomen. As this word is widely used, I will follow its common spelling in English, that is sangha.
} 
well as the acute dichotomy in terms of lifestyle, practices, and roles within religious institutions between ch'ulga ${ }^{3}$, the renouncers, and chaega ${ }^{4}$, the lay practitioners. Indeed, Buddhism in South Korea appears in several aspects like a two-speed religion.

However, such an opposition might fruitfully be questioned further, all the more since the current intensification of the relationships between monastics and laypersons brings important redefinitions of their respective identities. Nowadays, the development of Buddhist temples in urban areas as well as the growing popularity of retreats among lay practitioners seems to have reduced the distance between the Buddhist monasteries and the population. So, in the framework of the reflection about the so-called "division of religious labour", I would like to explore to what extent and limits this new spatial proximity does signify a rapprochement between the monastic and the lay Buddhists. In this paper, I focus on one case study, a one-week retreat program for lay practitioners that I observed in August 2008. I analyse the very ambiguity of a monastic-style retreat for laypersons, in order to enlighten what kind of relationship was built between the monks and the participants during this retreat, and how the monastic and lay identities were interacting and negotiated.

\section{The monastic-style retreats for laity, a case study}

Buddhism in twentieth century Korea has met with deep and sometimes fierce conflicts, between the ambition to reinforce its monastic basis, and the one to secularise and establish closer ties with the population. The main Buddhist organisation in South Korea, the Chogye Order, ${ }^{6}$ frequently stresses the importance of its monastic community in order to praise the authenticity and solidity of Korean Buddhism. For the same reason, this organisation has also attracted many critics for its distance with lay Buddhism and, more broadly, it is reproached with a lack of involvement in social issues. Since the 1980s and especially in the 1990s, the place and image of Buddhism within South Korean society have experienced many changes. Its rapid development in urban areas has changed the relationship between clerics and lay Buddhists, and also has raised important redefinitions in their identities and roles. In the urban temples, relations between clerics and laypersons have intensified, and many lay Buddhists started attending a temple nearby their home on a more frequent and regular basis than before. It has become a priority for a large number of monks and laypersons to elaborate new forms of religious organisation that would fit the needs and constraints of urban life. Many programs toward laity emerged, and occasions to study Buddhism have strongly increased. In the large cities, one can find numerous temples ${ }^{7}$ that organise classes and lectures on a wide range of doctrinal, cultural and practical aspects. In addition to these programs, demands and offers for more traditional forms of transmission have grown as well. Many Buddhists who live in Seoul and already attend a temple nearby their home also

\footnotetext{
${ }^{3}$ Ch'ulga 出家, (“leave home") refers to the Buddhist monks and nuns.

${ }^{4}$ Chaega 在家, (“at home", "householder") refers to the lay Buddhists.

5 «Division du travail religieux ». See Bourdieu, Pierre, 'Genèse et structure du champ religieux' (Genesis and Structure of the Religious Field), Revue française de sociologie, Vol. 12, No. 3 (1971), pp. 295-334.

${ }^{6}$ Chogye chong 曹溪宗.

7 In this paper I will use the terms (Buddhist) monastery and (Buddhist) temple interchangeably.
} 
attend mountain monasteries for different reasons: ceremonies, lectures, personal visits to monks. Besides, beyond the successful "Temple Stay" programs oriented toward tourism ${ }^{8}$ in those mountain monasteries, other programs were implemented which offer to laity to live for a while in a monastic manner in order to deepen their religious practice and knowledge.

The meditation retreat I will focus on here comes within the scope of this last tendency. It was organised in a monastery I will call S-sa, which is located on the slope of a mountain in the Kyŏnggi province and is renowned for its monastic practice of meditation. This retreat offered to lay Buddhists an initiation to kanwha sŏn ${ }^{9}$, led by a monk qualified by the Chogye Order to teach meditation. 17 participants (15 women, 2 men) took part in this one-week program where they followed a monastic- based lifestyle. They were between 45 and 65 years old, and were living in the city of Seoul or its close neighbourhood. Most of them were already attending an urban temple on a regular basis but they hardly had any experience of meditation when they started the retreat. This retreat program was not an occasional event, but had already taken place one time a year since 2005. It was created on the initiative of both monks from S-sa and laywomen attending this temple with two aims: to spread the teaching of kanhwa son meditation among the laity and also to set up a group of lay Buddhists ready to support the monastery. For the clerics as well as for the laypersons who took part in its organisation, this recently created program constituted an attempt to set up a new kind of relationship between the monastic community and the urban devotees, in a context of strong religious concurrence. Before this retreat program was implemented in 2005, devotees used to come only two or three time a year to S-sa, usually to make offerings to the monastic community. For this temple, remote from the urban centres, specialised in the monastic practice of meditation and lacking lay support, it has become a key concern to establish an active group of affiliated followers.

It was from a devotee laywoman I met in an urban temple where I was conducting field research that I came to know about this week of meditation, and agreed to take part in this program with her. With her help I was able to integrate

${ }^{8}$ The Temple Stay Program was created in 2002, at the occasion of the FIFA World Cup finals that took place in South Korea and Japan. First destined to foreigners, this program met with an important success among Koreans as well and is now broadly widespread among south Korean temples and monasteries.

${ }^{9}$ Kanhwa sŏn 看話禪. The kanhwa sŏn is a theory and method of meditation practiced in the sŏn 禪 (Chinese ch'an, Japanese zen) school of Buddhism. It lies on the observing of a critical phrase or $h w a d u$ 話頭 that aims at breaking through conceptual thought. In spite of redundancy, I will use the expression "kanhwa son meditation" in this paper for convenience of reading. Robert Buswell presents the ambiguous aim of kanhwa sŏn in these words: "In kanhwa practice, the meditator is not trying to achieve or to create awakening. Since Sŏn doctrine considers enlightenment to be innate in the minds of all sentient beings, enlightenment is not something that needs to be achieved or created; it is now, and indeed has always been, the fundamental fact underlying everyone's existence. The individual has, however, so thoroughly convince himself that he is not enlightened that he finds it virtually impossible to accept to accept that fact. Now utterly estranged from his true status as an enlightened person, the person must be taken through a period of transition - which his meditation practice provides - during which his true status is revealed to him and its frightening truth made acceptable.", Robert E. Buswell, The Zen Monastic Experience, p. 152. 
myself in this group of lay practitioners and I followed a participant observation methodology. ${ }^{10}$ Hence, this paper is principally based on information from daily observations, informal interviews with the participants and the monks, and data related to the organisation of the retreat. I introduced myself as a sociology student conducting fieldwork but in order not to call more attention than I already received as a young foreigner, I did not conduct long and recorded interviews. The formal interviews I refer to in this paper were conducted after the retreat, when I met the participants again or when I came back to the temple. The main data used in this paper was established during the retreat, but the contextualisation and interpretation also come from broader ethnographic field researches I conducted in other South Korean Buddhist temples for about 16 months between 2006 and 2009. ${ }^{11}$

\section{Distance between Buddhist clergy and laity}

During the twentieth century, the history of Korean Buddhism was characterised by several undertakings in its revitalization, modernization and development. During the Japanese colonization however, reform movements that tended toward a greater secularization received ambiguous support from the Japanese administration. As colonization went on, these movements were finally discredited among a growing number of Buddhists, and were accused of serving the colonial ambition of controlling the Korean sangha. ${ }^{12}$ As Robert E. Buswell ${ }^{13}$ and Henrik H. Sørensen ${ }^{14}$ observed: after the colonization, new leaders of Korean Buddhism opposed this trend toward secularization, then seen as a sign of Japanese influence. Instead, in the name of authenticity and while referring to Koryŏ and Silla Buddhism, they advocated the restoration of a tradition based on the monastic, celibate and ascetic sangha. Furthermore, this mistrust towards the secularization movement was reinforced by the fierce conflict between married and celibate clerics that profoundly divided the Buddhist community from the 1950s to at least the 1970s. ${ }^{15}$ During this conflict, the Chogye Order reinforced its identity as a community of celibate clerics,

\footnotetext{
${ }^{10}$ Actually, during the retreat, even if everybody knew that my reason for coming was related to academic study and not Buddhist conviction, I chose not to keep out from any activities and for example took part to the precept ceremony. When asked about my religious belonging, I answered that I did not see myself as a Buddhist but was interested in Korean Buddhism and in the practice of meditation, and this answer, even if vague, was willingly accepted by both monks and lay participants.

${ }^{11}$ These researches were conducted in the context of a Ph.D. dissertation I am preparing. Their major part was supported by the Korea Foundation's program for field research.

${ }^{12}$ Sørensen, Henrik H., 'Buddhism and Secular Power in Twentieth-Century Korea', in Harris Ian (ed.), Buddhism and Politics in Twentieth-Century Asia (London and New-York: Pinter, 1999), p. 133.

${ }^{13}$ Buswell, Robert E., 'The Emergence of a "Korean" Buddhist Tradition', in Geumgang Center for Buddhist Studies (ed.), Korean Buddhism in East Asian Perspective: Seoul) Jimoondang, 2004), p. 32.

${ }^{14}$ Sørensen, Henrik H., 'Buddhism and Secular Power in Twentieth-Century Korea', p. 136.

15 The so called "purification movement" (Chunghwa undong) was initiated by the president Yi Sŭngman (Syngman Rhee), the 20th of may 1954, when he commanded the married clerics to leave the Buddhist clergy and its monasteries in the name of the expurgation of the Japanese customs. This movement led to violent fights between the supporters of clerical marriage and its opponents over legitimacy and temple's property. This conflict was said to have ended with the creation of two separates orders (Chogye-jong in 1962, Taego-jong in 1970) but in fact, tensions and sometimes fights went on, long after this official solving.
} 
living in accordance with the Buddhist monastic rules ${ }^{16}$. It was only in the $1980 \mathrm{~s}$, that the Chogye Order effectively stressed the development of its relations with the laity.

Confronted with this distance from the clergy, many lay Buddhists gathered together in order to organise teachings and lectures, and to reflect on a means to reform Buddhist institutions. Sharp critics were expressed against the Buddhist clergy, reproaching it with neglecting the laity and the spreading of Buddhist's teachings. ${ }^{17}$ Among both religious and lay Buddhist reformists, the promotion of a deeper education and training were important claims. When the movement for the renovation and generalization of Buddhist education among monks and nuns effectively started in the 1980 s, it played an important role in the revitalization of Korean Sangha. It was accompanied by a strong ambition to develop religious education, and to spread the basic knowledge of Buddhist teachings among the lay followers as well. ${ }^{18}$ The emphasis placed on religious education and on the spreading of doctrine, has been a key feature in the urban development of Buddhism. Among the clergy, it is justified in the name of the Mahayana ${ }^{19}$ identity of Korean Buddhism but it is also a way for the Chogye Order to enforce its position in a context of religious concurrence. In the Buddhist temples of Seoul, the availability of classes has recently and rapidly increased, ranging from introductory lectures to advanced courses in the study of sutra in Chinese characters. Additionally, more specific courses like "Buddhism in English" 20 , tado ${ }^{21}$, meditation, Buddhist arts, etc. emerged as well and acquired a large popularity. In the case of P-sa, an active monastery located in Kangnam, there were more than ten weekly programs directed toward the Buddhist formation of laity by the year of 2008 .

In this context of the growing interest in Buddhist knowledge amongst the South Korean population, some practices that used to be mostly monastic have gained some popularity among the lay Buddhists as well. It is, in particular, the case of kanhwa sŏn meditation that has tended to become a model and reference for lay practice as well. Even if it remains marginal in facts, a growing number of laypersons wants to learn and practice this form of meditation. Therefore, questions about the modalities and the ways for laypersons to receive training in the practice of kanhwa sŏn have become important concerns for Buddhist lay groups and for the Chogye Order's Office of propagation ${ }^{22}$ of the Chogye Order. Programs and lectures for the laity to learn about the practice of sŏn meditation have emerged in temples, and in 2005 a guide of kanhwa sŏn meditation was published, which was designed by the

\footnotetext{
${ }^{16}$ Kyeyul 戒律 (Sanskrit: vinaya) refers to the rules regulating the Buddhist monastic life.

17 These critics were particularly expressed by the movement of Minjung Buddhism. On this point, see Chung Byung-jo, 'The Buddhist Lay Movement in Korean Society', in Lancaster Lewis R. and Payne Richard K (ed.), Religion and Society in Contemporary Korea (Berkeley: Institute of East Asian Studies, University of California, 1997), p. 91.

18 Taehan Pulgyo Chogyejong Kyoyugwŏn (ed.), Chogyejong sa kŭnhyondaep'yŏn (Contemporary history of the Chogye Order) (Seoul: Chogyejong ch'ulp'ansa, 2005), pp. 278-287.

${ }^{19}$ Taesŭng pulgyo 大乘佛敉 (Sanskrit : mahāyāna), literally "Great Vehicle".

${ }^{20}$ Sometimes designed for foreigners, these classes are more generally organised for Koreans who want to learn English and Buddhist doctrines and history together.

${ }^{21}$ Tado 茶道, literally "way of tea”.

${ }^{22}$ P'ogyowón 布教院.
} 
Chogye Order as a reference handbook. ${ }^{23}$ However, this form of meditation is said to require a relationship with an experienced teacher, ${ }^{24}$ usually a monk or a nun, and such relations are difficult to establish in the busy monasteries of Seoul. ${ }^{25}$ Therefore, during my field research, many Buddhists interested in intensive practices and meditation pointed out the limits of such programs and regretted that they did not allow participants to develop a direct relationship with a meditation teacher. Regrets and even criticisms concerning the discrepancy between the training and formation of the clerics, and those that are available to the laity are frequently heard, particularly from engaged lay groups who reproach the Chogye Order for a lack of social investment.

In this context of a significant distance between the monastic community and the laity, lay Buddhists described the meditation retreat, organised in S-sa with a well-experienced sŏn teacher, as an outstanding opportunity. This retreat allowed participants to introduce themselves to kanhwa sŏn meditation and to receive a hwadu directly from a meditation teacher. During the retreat, these points were highlighted by participants and monks and were described as an exceptional chance of accessing a part of Buddhism generally not available in the collective courses organised by the urban temples. In addition, the high status of the meditation monk who was leading the retreat was also praised. Before and after the retreat, participants described this direct access to a "meditation monk" as exceptional and distinctive. A laywoman in the initiative of the program who was also heavily involved in the Seoul monastery of $\mathrm{P}$-sa, introduced this retreat to the active lay devotees she knew. She presented it as a rare opportunity reserved for those who had already proved their involvement into Buddhist activities. Technically, everybody was allowed to enrol in this program as long as there were places available. However, it was described among the P-sa laypersons who knew about it, as a difficult and exceptional experience reserved for advanced Buddhist only. ${ }^{26}$

\section{Forms and contents of teachings during the retreat}

Each day of the retreat, excluding the first and last, the monk in charge of the meditation training at S-sa (Sönwŏnjang) ${ }^{27}$ gave two hours of lecture. With four other meditation teachers, this monk was a contributor to the Chogye Order's official meditation guide, Kanhwa sŏn. All participants received this book and it was used as a handbook during the lectures. Teachings were mainly focused on the theories and stories related to kanhwa sŏn, but more broadly, the sŏnwŏnjang presented also the doctrinal basis of Buddhism, in particular the concepts of yŏngi, "chain of

23 Taehan Pulgyo Chogyejong Kyoyukwŏn Purhak Yŏn'guso and Chon'guk Sŏnwŏn Sujwahoe P'yŏnch'an Wiwŏnhoe (ed.). Kanhwa Sŏn. Chogyejong Suhaengŭi kil (Kanhwa Sŏn. The Chogye Order Way of Practice) (Seoul: Chogyejong Ch'ulp'ansa, 2005).

${ }^{24}$ This point is regularly highlighted during teachings on meditation, and in the mentioned reference book of the Chogye Order, several parts deal with the importance of the direct supervision of an experienced meditation teacher.

${ }^{25}$ Some lay groups also organise meditation training, but generally in accordance with other traditions (Vipassana in particular) than the kanhwa sön that remains a very monastic practice.

${ }^{26}$ For this reason, the organiser first refused my participation and when she finally accepted, insisted on how grateful I should be to the laywoman who took up my cause.

${ }^{27}$ Sŏnwŏnjang 禪院長. 
interdependent origination" 28 and chungdo, "middle way"29. The general history of Buddhism and the place of Korean traditions within it were also important parts of these teachings. These lectures did not focus much on the polemical points of the history of Korean Buddhism and instead, presented to the participants the currently shared doctrinal basis of the Chogye Order. Buddhist canons were not directly used during these classes but when the sŏnwŏnjang was referring to doctrinal texts or concepts, he frequently indicated the relative expressions in Chinese characters on a board. He also frequently asked participants to refer to their guidebook, where short excerpts from classical texts were presented both in Korean and in classical Chinese. The content of these lectures was sometimes advanced and the participants said that it was not easy to understand, but they nonetheless praised the pedagogical aspects of these teachings. Intertwined with theoretical reflections, the sönwönjang also developed on the adequate ways to lead one's life and on the concrete applications of Buddhist teachings to everyday life. He designated the realisation of enlightenment as the very goal of the practice but also emphasised that the process itself was nonetheless important. This led him to present the multiple positive consequences that the son meditation was supposed to bring in terms of health, happiness, and relationships to both the practitioner and the whole of society as well.

In their content as in their form, these teachings were not very different from the lectures on meditation found in urban temples. Specificities of this retreat were more to find in informal teachings. The monastic lifestyle of the retreat was very new for almost all the participants, and therefore the leader of the lay group as well as the head of the monastery played an important role in presenting the rules and proper conduct. They taught the participants concrete etiquettes and customs, like the way to properly arrange shoes before entering the temple, the required positions of the hands when walking, and the manner to hold a cup of tea. They also described in detail more sophisticated behaviours, in particular the rules and different steps of the monastic formal meal ${ }^{30}$ that was taken at noon. Bodily practices to relieve the pain resulting from keeping the meditation position were also explained by the monks. ${ }^{31}$ All these teachings were a part of the demanding socialisation to the monastery's lifestyle. Participants who had been attending Buddhist temples for a long time generally ignored them, or in the case of the formal meal, some had heard about these customs but never had the occasion to familiarise with them. These rules and customs were presented not only as habits or etiquette, but also, in a Buddhist perspective, as a way to practice the kanhwa sŏn meditation in daily life. Every day, after the formal meal, the sŏnwŏnjang gave instructions concerning the proper meditative behaviour according to daily activities. He also underlined that these behaviours rules ${ }^{32}$ and the respect of Buddhist precepts were essential in order to extend the meditation practice beyond the times of formal sitting meditation. The main originality of the retreat,

28 Yŏngi 緣起 (sanscrit: pratītya-samutpāda). This Buddhist concept means the interrelations between all phenomena.

${ }^{29}$ Chungdo 中道 (sanscrit: madhyamā-pratipad). This Buddhist formula has a wide range of meaning but often refers to the avoidance of extremes.

${ }^{30}$ Palu kongyang 鉢孟供養.

${ }^{31}$ In particular manners to position the body when sitting, stretching movements, positions to relieve joints pain...

32 At this occasion, he talked about principles of the monastic etiquette and also about rules related to geomantic theories (pungsu 風水) (concerning ways to enter a room or a temple, manner to prepare and drink tea...). 
compared to lectures and courses one could generally find at urban temples, lies in these practical and rather informal teachings given in the context of daily activities.

\section{An intensive monastic socialization}

The organisation of the retreat aimed at separating the participants from their everyday habits and plunged them into the rhythm and rules of the traditional monastic life. First, a clear continuity was build between the monastic and lay retreats. In Buddhist monastic communities, one year is generally divided in four parts. During 100 days in winter and 100 days in summer, intensive retreats $(\text { kyŏlche })^{33}$ are organised. Between these retreats are time for movements and diverse activities (haeje $)^{34}$. In S-sa, retreats for laity took place exactly after the end of the three months summer retreat, and this continuity between the retreat of the monks and the laity was explicitly emphasised. During the monastic retreat periods, the monastery received a large number of monks, but when the lay retreat started, all had left. The monastery compound was devoted to the lay participants and only three clerics were present: the monk responsible for meditation teaching (sŏnwŏnjang), the head of the monastery (chuji) ${ }^{35}$ and a younger monk. Participants stayed in rooms that are ordinarily used by monks and they also practiced meditation in the main meditation hall, which - apart from this circumstance - was forbidden to the laity or at least had very limited access. After the departure of most of the monks at the end of their retreat, it was then occupied by laypersons to follow the way of monastic life for a week. During its opening speech, after having described the rules that participants had to follow, the monk in charge of the meditation training advised them to live on the same pattern as monks do: "You should live like sünims ${ }^{36}$ in monasteries, and you should do as those who practice correctly do."37

Schedule and rules of the retreat were modelled on monastic ones. Lay participants put on traditional outfits (grey and white for women, blue for men). ${ }^{38}$ Books, radio and music players were prohibited, as well as the use of make-up and perfumed cosmetics. ${ }^{39}$ Monks asked laity to restrain from using mobile phone and to separate themselves as much as possible from their familial and/or professional life. In addition, participants were encouraged to limit their talks and to focus only on the meditation practice. During the retreat, the schedule was also modelled on the monk's one: from 3am to 9pm, participants shared their time between ceremonies (with bows and prayers), classes on meditation and Buddhism, meditation training, and collective

\footnotetext{
33 Kyŏlche 結制.

${ }^{34}$ Haeje 解制.

${ }^{35}$ Chuji 住持.

${ }^{36}$ Sünim is a respectful term, widely used when addressing monks and nuns or when referring to them.

${ }^{37}$ Extract from the retreat's opening speech by the monk in charge of the meditation training, recorded the $22^{\text {nd }}$ of August 2008.

${ }^{38}$ These clothes are not specific to the Buddhist clergy. They are designed in a Korean style and are generally worn by lay devotees as well as by monks and nuns. The distinctive clerical outfit is a brown dress ( $k a s a$ 袈乷) worn by clerics on their regular clothes for ceremonies or formal occasions.

39 Drinking alcohol and smoking cigarettes were also forbidden, but this is a general rule in Buddhist temples.
} 
works. A complete meal was served at noon, and, as it was recommended to avoid food in the morning and in the evening, only snacks ${ }^{40}$ were served then. ${ }^{41}$ In addition, participants were asked to stop using the terms normally used to address each other in society. Instead they had to call laywomen exclusively posallim ${ }^{42}$, and laymen kosanim $^{43}$, and to only use polite forms when talking to each other, regardless of age and gender.

Table 1 : Daily schedule of the retreat.

\begin{tabular}{|l|l|}
\hline 3:00 4:00 & Yebul (ceremony) $^{44}$ and 108 prostrations \\
\hline 4:00 5:00 & Meditation training \\
\hline $5: 50 \sim 6: 30$ & Breakfast time \\
\hline 7:00 7:30 & Ullǒk (Collective work) $)^{45}$ \\
\hline $8: 00 \sim 10: 00$ & Lecture by the monk in charge of the meditation training \\
\hline 10:30 & Sasimaji (ceremony) 4 \\
\hline 11:30 & Lunch \\
\hline 2:00 4:00 & Meditation training \\
\hline 4:30 5:00 & Cleaning of the monastery \\
\hline $5: 00 \sim 5: 30$ & Tea and snacks \\
\hline $6: 00 \sim 9: 00$ & Yebul and meditation training \\
\hline 9:00 & Sleep \\
\hline
\end{tabular}

At the beginning of the retreat, the monk in charge of meditation and the head of the monastery, both gave instructions aiming at separating the days of retreat from everyday life (ilsang saenghwal). The idea prevailing in the retreat's organisation was to encourage separation from the outside world and the concerns of everyday life. Participants were advised to leave their mundane habits and to follow monastic rules and rhythm in order to focus all their efforts toward the continuity of meditative concentration. The meditation monk emphasised that the short time of the retreat should be a time away from worldly concerns, as well as from the worldly knowledge and references.

"Therefore, if you leave intelligence, leave the mundane intelligence... If you

\footnotetext{
${ }^{40}$ Monks recommended participants not to eat in the morning and in the evening. However, they said that if it was not possible to follow this recommendation, snacks would be served. Snacks consisted in rice porridge in the morning, rice cakes and fruits in the evening.

${ }^{41} \mathrm{Cf}$. Table 1 for daily schedule.

${ }^{42}$ The expression posallim is very generally used when talking or referring to a Buddhist lay woman.

${ }^{43}$ The expression kŏsanim is largely used when talking or referring to a Buddhist lay man.

${ }^{44}$ The yebul 禮佛 is the Buddhist daily ceremony.

${ }^{45}$ Ullyŏk 運力 refers to collective work.

${ }^{46}$ Sasimaji 已時摩旨. During this morning ceremony of offerings, cooked rice is offered to the Buddha.
} 
just empty your heart-mind, before you go back [home], you will have attained something great. You will really understand the deep meaning of sŏn, and then you will leave with a sure and clear heart-mind. But, during the retreat, if you cannot empty your heart-mind, if you want to understand són Buddhism with mundane intelligence, then, before you leave, it will only bring about confusion." 47

During interviews and informal talks with the participants, the monastic and ascetic rules framing the retreat were described as difficult, but also as important aspects of what was expected in a quite remote meditation monastery. Most of them put a stress on the authenticity and purity of the mountains monastery's lifestyle, and they sometimes clearly contrasted S-sa with the urban monasteries, said to be noisy and easily contaminated by worldly confusion.

"If temples are located in town, there is really much prosperity, if there is much prosperity... there is pollution. Because, when it happens that impure things get into water, it is called pollution. This can happen. But until now, in $\mathrm{S}$-sa, it is clean as you know. Let's just think about $\mathrm{P}-\mathrm{sa}^{48}$ in downtown Seoul that is visited by all kind of people. There are continually people going back and forth... In town, they say: "I only pray for me", "I care only for myself". That kind of prayers, they are called kibok ${ }^{49}$. There are quite a lot of them in urban temples... In our S-sa, the meditation sünim are without greed, they think: "I have to awake myself quickly to save all living beings"... As they only follow this rule, $\mathrm{S}$-sa is really a clean place. It remains pure." 50

While the adaptation of Buddhist institutions to the urban contemporary life is a key concern among lay and clerical Buddhists, the traditional lifestyle of the monastic sangha enjoys an important prestige.

\section{A one-week monastic experience?}

Retreat offers an experience of monastic renunciation life, but, and this is also important, on a temporary basis. ${ }^{51}$ While the ascetic and outworldly dimension of the retreat was constantly valued, the idea that the return to everyday life will occur in a few days was also constantly present. During his teaching, the meditation monk stressed several times that the things the participants were learning in the monastery should not be limited to the retreat, but were to be continuously used in the worldly life. The sŏnwŏnjang exhorted advised participants to keep focusing on hwadu at home and at every moment of their lives, and explained several times how a diligent

${ }^{47}$ Extract from the retreat's opening speech by the monk in charge of the meditation training. Recorded the 22nd of August 2008. Translated from Korean by the author.

${ }^{48} \mathrm{P}$-sa is an active temple in Seoul this person used to attend frequently.

49 Kibok 祈福.

${ }^{50}$ Extract from an interview with a leading laywoman from the S-sa lay followers group. This interview was recorded after the retreat, the $9^{\text {th }}$ of December 2008. Translated from Korean by the author.

51 This double-sided characteristic appears clearly in the expression "tan'gi ch'ulga" (temporary renunciation). This expression is now in use in programs that are generally longer (one to three months) than the one we focus on here, but the presence together of both ideas of monastic renunciation and temporary experience were as well present in this shorter retreat. 
practice could efficiently change them. Also, he frequently illustrated his teaching with references to the audience's everyday life, and emphasise how the meditation practice could help them to improve their relationships with their relatives and to overcome domestic and professional stress. This monastic experience was directed toward a reintegration in everyday life, and this return was the always-present horizon of the retreat.

In contrast to the recommendations of the meditation monk who encouraged participants to cut themselves off temporarily from their daily customs, separation from worldly concerns and ascetic discipline were moderate in practice among the lay practitioners. All followed the strict schedule of the temple, but some other rules, like the limitation of food and talks, were only partially respected. Most of the participants called their families on their mobile phones everyday and, during their free time, all enjoyed jokes and lively talks about their lives, children, temples they had attended, etc. Informal meals were an occasion for sharing advice about food, and the laywoman who was working and cooking at the monastery ${ }^{52}$ received a lot of questions about the specificities of this so-called "temple food". 53 The retreat's atmosphere was studious during formal activities, but at other times, it was more relaxed and sometimes even recreational.

Throughout the retreat, participants diligently attended all the teachings, meditation sessions and collective tasks. But, most of them also frequently noted the difficulty of such a lifestyle. By second day, several people asked to shorten the last meditation session in the evening, explaining it was too hard and painful for their backs and joints. At this occasion, many expressed their difficulties to the meditation monk who gave them some advice to relieve or overcome their physical pain and to understand the meditation practice more precisely. All the lay practitioners expressed intense pain after numerous hours spent in the half-lotus position. The hardness brought about by the retreat's schedule and training frequently lead both lay persons and monks to stress the difference between the lay and the monastic ways of life, as well as the intense and difficult training required by the monastic lifestyle. At the end of the retreat, differences were clearly reaffirmed between those who had been through a temporary monastic experience and those who had chosen this way on a permanent basis. The following anecdote illustrates it: on the last day, whereas some lay participants were delighted to return home and to recover from the strain of the retreat, the head monk pointed out that he had no home outside and he will not leave the monastery.

\footnotetext{
${ }^{52}$ In most temples and male monasteries, there are laywomen who care for the food and meals. Generally, she or they is/are employed by the temple and earn wages, and may be aided by novices or volunteer lay devotees.

${ }_{53}$ Nowadays, the temple food (chŏl ŭmsik) attracts a lot of attention among the Buddhists and more generally among the South Korean society. Korean Buddhist monks and nuns are committed not to eating meat and fish, as well as categories of vegetables said to intensify sexual desire or aggressiveness. Monastic food is also reputed to respect the natural taste and form of ingredients and to be free from artificial additives. The recent popularity of monastic diet in Korea combines together concerns related to health, authenticity, economy and Korean identity. On this question, see Moon, Seungsook, 'Buddhist Temple Food in South Korea: Interest and Agency in the Reinvention of Tradition in the Age of Globalization', Korea Journal Vol. 48, No. 4 (2008), pp.147-180.
} 


\section{Integration of laity as followers affiliated with the monastery}

The participants left the retreat not as temporary monks but as lay followers. While this week brought the monks and the laity closer, it also led to the integration of participants as clients of the monastery. At the origin of this program, two aims were tightly intertwined: spreading kanhwa sŏn meditation teaching among the laity and also setting up a group of lay devotees who can support the monastery. In any case, implementing a long-term relationship between participants and the temple was a key concern for both lay and monastic organisers. The retreat ended on a final ceremony where all participants took the five Buddhist lay precepts ${ }^{54}$ and received a light burn from an incense stick ${ }^{55}$. At this occasion, the sŏnwŏnjang gave a Buddhist name ${ }^{56}$ to each person who wanted to receive one. ${ }^{57}$ Again, the head monk and the lay group leader encouraged all the participants to keep their relationship with the temple alive and to join together as the " 4 th class" group, as this was the fourth retreat to be organised.

On several occasions, the sŏnwŏnjang presented this retreat as a first step toward his dream to open a "citizens meditation centre" ( $\operatorname{simin}$ sŏnwŏn), where lay Buddhists would be able to attend the three months retreats in the winter and summer at the same time and pattern as the monks, even if not in the same meditation hall. When I asked the head monk about the origin of the retreat program, he mentioned this concern to give the laity an opportunity to practice meditation and described the aspiration of the sonwönjang to create a place where renouncers (ch'ulga) and householders (chaega) could practice asceticism together. ${ }^{58}$

Hence, the teaching of meditation was directed toward its extension beyond the retreat's time, and this intensive training was presented by the sŏnwönjang as an occasion for lay Buddhists to establish a long-term relationship with an experienced teacher. He stressed the importance for lay Buddhists to continue their training, and to regularly contact him for direct supervision of their practice. Afterwards, some practitioners asked for meeting him personally and at these occasions he gave them more concrete and precise instructions concerning the way they should practice meditation and sometimes taught them additional techniques to overcome obstacles in their training. ${ }^{59}$ However, only a small minority of participants followed this direction. The more general attitude was to listen to the monk's teachings with interest, but without trying to develop further this leader-follower relationship.

When I interviewed the lay devotee, who was involved in the organisation of

${ }^{54}$ The five Buddhist lay precepts prohibit killing, stealing, sexual misconduct, language misconduct, and substances like alcohol and drugs.

${ }^{55}$ Yŏnbi 燃臂. This is a common ceremony that accompanied the engagement to the five Buddhist lay precepts. See Robert E. Buswell, The Zen Monastic Experience, p. 142.

${ }^{56}$ Pŏmmyŏng 法名.

${ }^{57}$ About half of the participants had already received a Buddhist name before attending the retreat. Those who had no Buddhist name received one at this occasion, but among those who had already one, many chose to receive a new one from the sŏnwŏnjang, as he was a recognised meditation monk

${ }_{58}^{58}$ Data from an interview with the head monk of S-sa, recorded on December $9^{\text {th }} 2008$.

59 For example, for practitioners who suffered from severe headache while meditating, he diagnosed a problem of energy ( $k i$ 氣) and individually taught them breathing techniques aiming at regulating their $k i$. 
the retreat since the beginning, she stressed her desire to help this temple and its monastic community. She said that about eight years ago, in agreement with the previous head monk, she attempted to set up a group of lay followers (huwŏnhoe) ${ }^{60}$, but encountered many difficulties because of the poor accessibility of the temple. ${ }^{61}$ The organisation of lay retreats started in 2005, when the head monk suggested creating a meditation training in order to encourage laypersons to come to the temple despite its remoteness. She now strongly values the practice of kanhwa sŏn meditation and the exceptionality of S-sa as a monastery of meditating ascetic monks, but she explained that first, she essentially saw such meditation programs as a way to constitute a group of followers for the temple.

"We wanted to create a support group and then help the temple... So I asked the previous chuji sunim for advice and he told me that we should try to do sŏn. So first, I answered that I was not able to so: "I can't do that. Only staring at a wall, while sitting during five nights and six days... I just can't. Instead, I would prefer to do 3000 prostrations, but I can't do sŏn." The monk said to me that we should try. "From now on, if we say that we are Buddhists, we should do sŏn meditation". So, at first, I started to try to meditate against my will, in order to set up a support group... I thought that if I don't do meditation, others will not do so either, and then nobody will support the temple... So I gathered 14 people... It was really hard, but I did it that way... First, I did not think: "I have to attain enlightenment", "sŏn is a good thing", but rather "how should I do in order to set up a support group". Therefore, I almost slept during the first practice., $" 62$

This person at the initiative of the program expressed a particular reluctance toward meditation. Even if most of the participants did not share such reluctance, they all had ambivalent expectations toward the retreat program, which consisted in an ascetic training on the one hand, and an occasion to affiliate lay devotees with the monastery on the other hand. When they spontaneously spoke about their reasons for attending the retreat or when they answered my questions, all voiced their interest and curiosity toward the practice of meditation and the monastic ascetic lifestyle. Among the 17 participants, only two women had already practiced kanhwa sŏn and the others had not experienced such training before coming. Being closer to teaching monks that are highly valued but said to be not easily approachable, were important reasons for enrolling in this program. Many participants expressed their satisfaction with meeting a highly regarded teacher and with involving themselves to a form of Buddhism seen as more authentic than common prayers. Except for a small minority, they described meditation as hard and generally not very pleasant, but nonetheless emphasised its importance as a reference of the correct way to practice Buddhism. At the end of this retreat, the exceptionality and exemplarity of S-sa were stressed to explain why they wanted to support this monastery.

Even without involving themselves in the practice of $h w a d u$ and maintaining regular interviews with the meditation monk, almost all participants at this retreat established a close relationship with the monastery, at least during the year that

\footnotetext{
${ }^{60}$ Huwŏnhoe 後援會.

${ }^{61}$ As there are no bus service nearby and unless one has a car, it takes several hours to walk to reach S-sa.

${ }^{62}$ Extract from an interview conducted on December $9^{\text {th }} 2008$. Translated from Korean by the author.
} 
followed. ${ }^{63}$ At the end of the retreat, participants received a wide range of information concerning the different meetings among the lay followers of the temple and the program of teachings. The head monk and the lay organiser of the retreat encouraged participants to attend meetings regularly, already organised with the devotees who had attended previous retreats. This program featured two monthly gatherings, which were two-hour lectures given by the sŏnwŏnjang on kanhwa sŏn meditation and two-hour meditation sessions. A schedule was also established to share responsibilities amongst devotees, like for example, making food offerings or driving others from Seoul to the temple. These activities were mainly organised on weekdays and were directed toward the laywomen who had no professional activities. Laymen, who were a small minority, were instead encouraged to take part in the teachings organised towards them on Sundays, mostly for availability reasons but also explicitly to socialise the male devotees together. About one year after this 2008 retreat, 12 (ten women, two men) out of the retreat's 17 participants, were still attending S-sa. They had been coming for the ceremonies, teachings, meditation sessions, and also for voluntary work (like the preparation of kimchi before the winter monastic retreat). In addition, most of them frequently made donations ${ }^{64}$ and offerings, and asked monks for both regular and exceptional prayers ${ }^{65}$. Hence this fourth retreat raised the number of lay supporters, regularly coming to the temple, to 40. Although this program is still at its beginning, the retreats have rapidly led to the development of an affiliated team of lay followers, who actively support the monastery in terms of funding and organisation.

\section{Conclusion}

At the time of the retreat, lay practitioners immerged themselves into a deep training based on the monastic model. At this occasion, they could practice kanhwa sŏn meditation, learn about Buddhist doctrines and possibly establish a personal relationship with a monk recognised for his teaching on meditation. Apart from a small minority, participants did not pursue the way suggested by the monk in charge of the meditation training, and after the retreat only practised meditation occasionally, usually at the monthly meditation session at S-sa. However, strong interest for kanhwa sŏn appeared to be nonetheless present among lay devotees. During formal or informal interviews, all talked about their practice of prayers or bowings but stressed

\footnotetext{
${ }^{63}$ Because of the short time that had passed since the retreat in 2008, this fieldwork does not allow the assessment of the strength of this affiliation. Further research is needed, but we can already look at the previous retreats. After the first and the second one, almost all the participants kept attending S-sa, but after the third one nearly no one has maintained a relationship with the temple. Hence, before the holding of the fourth retreat I presented in this paper, 28 followers were supporting the monastery and regularly attending its programs.

${ }_{64}$ Devotees generally give some money when they visit a Buddhist temple and can make larger donations for a special occasion or request. Besides this, members of the lay group decided to ask each follower a predetermined sum of 30.000 Korean won (in the summer 2008 , about 20 euros) every month in order to support the monastery and its community.

${ }^{65}$ Almost all participants had asked for regular prayers for their families or for one hundred days of prayer (paek il kido) at the monastic winter retreat. Some followers also asked the head monk for exceptional prayers: for example to help them to overcome relationship difficulties or for the University Entrance Examination (taehak suhak nŭngnyŏk sihŏm). These requests were accompanied with money considered as an offering.
} 
that these should be done in a perspective of Buddhist cultivation, ${ }^{66}$ and as a first step towards a deeper training with kanhwa sŏn meditation and asceticism. ${ }^{67}$ Even if rare within lay practices, meditation is still highly valued and this retreat seems to have even reinforced its position among the participants as a reference for an authentic way of Buddhism.

By experiencing for a short time an ascetic lifestyle, most participants were led to assess the specialization and virtuosity it requires, while also learning about its importance and justification in a Buddhist's search for enlightenment. This retreat I presented here is not an isolated case. Since the mid 1990's, programs offering temporary monastic experience for laypersons have gained popularity and many are currently implemented. This tends to spread some of the norms and practices that were previously mostly confined to a small number of monks and nuns - for example seeking personal transformation through meditation -, among the lay Buddhists or at least to emphasise them as more generalised models for religious conducts. "Nowadays, enlightenment interests many people" as I heard several times during my field research. The S-sa head monk also observed that: "In Buddhism there are several ways, including the ways of the bodhisattvas, but currently, a growing number of lay devotees, posallim, wants to reach enlightenment within this present life. Therefore, we plan to create a meditation hall for the laity and more facilities in order to organise longer retreats for laypersons." 68 This phenomenon tends to bring lay devotees and monks closer, and to blur some aspects of the border between them. ${ }^{69}$ However it also leads to a renewed affirmation of their differences. My argument is that the relative opening of monasteries and the development of sophisticated forms of Buddhism among laypersons in South Korea, contributes to both challenge and strengthen the distinction between the monastics and the laity. Temporary "monastic experiences" are moments of intense socialization to the norms and values of the Buddhist monastic institutions, they bring closer lay devotees and monastics, but also contribute to the legitimization of monks as guides and references for the lay followers.

\footnotetext{
${ }^{66}$ That is, with a concentrated heart-mind focused towards self-transformation, not as a way to receive good fortune (kibok).

${ }^{67}$ This advanced step was expected within the current life or the next one.

${ }^{68}$ This citation is extracted from an informal interview conducted with the chuji from S-sa during the retreat organised in August 2008, and translated from Korean by the author.

${ }^{69}$ This tendency shows similarities with some of the observations conducted by Richard Gombrich and Gananath Obeyesekere in Sri Lanka, in particular when they analyse how the development of meditation among the lay Buddhists has contributed to challenge the hierarchy and the distinction between clergy and laity. See Gombrich, Pace Richard F., and Gananath Obeysekere, Buddhism Transformed: Religious Change in Sri Lanka (Princeton: Princeton University Press, 1988), pp. 225-240.
} 


\section{References used in this paper}

Bourdieu, Pierre, 'Genèse et structure du champ religieux' (Genesis and Structure of the Religious Field), Revue française de sociologie, Vol. 12, No. 3 (1971), pp. 295-334

Buswell, Robert E., The Zen Monastic Experience. Buddhist Practice in Contemporary Korea (Princeton: Princeton University Press, 1992)

Buswell, Robert E., 'The Emergence of a "Korean" Buddhist Tradition', in Geumgang Center for Buddhist Studies (ed.), Korean Buddhism in East Asian Perspective : Seoul)Jimoondang, 2004), pp. 23-46

Chung Byung-jo, 'The Buddhist Lay Movement in Korean Society', in Lancaster Lewis R. and Payne Richard K (ed.), Religion and Society in Contemporary Korea (Berkeley: Institute of East Asian Studies, University of California, 1997), pp. 87-100

Gombrich, Pace Richard F., and Gananath Obeysekere. Buddhism Transformed: Religious Change in Sri Lanka (Princeton: Princeton University Press, 1988)

Moon, Seungsook, 'Buddhist Temple Food in South Korea: Interest and Agency in the Reinvention of Tradition in the Age of Globalization', Korea Journal Vol. 48, No. 4 (2008), pp.147-180

Sørensen, Henrik H., 'Buddhism and Secular Power in Twentieth-Century Korea', in Harris Ian (ed.), Buddhism and Politics in Twentieth-Century Asia (London and New-York: Pinter, 1999), pp. 127-154

Taehan Pulgyo Chogyejong Kyoyugwŏn (ed.), Chogyejong sa kŭnhyondaep’yŏn (Contemporary history of the Chogye Order), (Seoul: Chogyejong ch'ulp'ansa, 2005)

Taehan Pulgyo Chogyejong Kyoyukwŏn Purhak Yŏn' guso and Chon'guk Sŏnwŏn Sujwahoe P'yŏnch'an Wiwŏnhoe (ed.), Kanhwa Sŏn. Chogyejong Suhaengŭi kil (Kanhwa Són. The Chogye Order Way of Practice) (Seoul: Chogyejong Ch'ulp'ansa, 2005) 